\title{
Introduction: On Portuguese Cinema
}

\author{
CLARA ROWLAND \\ Universidade Nova de Lisboa \\ ESTELA VIEIRA \\ Indiana Univerity Bloomington
}

A sequence from João César Monteiro's Veredas (1978) depicts a fragment of Aeschylus's The Eumenides through a peculiar dialogue: Athena, atop a mountain in the northern Portuguese region of Trás-os-Montes, addresses a choral group of the traditional Cante Alentejano. This group then answers her, in the reverse shot, from the fields of the Alentejo region in southern Portugal. In another sequence, this time from João Botelho's Um adeus português (1986), a film that recreates an assumedly fake African landscape not far from Lisbon, in the Tapada de Mafra, a group of African boys attend a lesson focused on the major rivers of Portugal. There is a strange discrepancy in the scene between the boys' reality and the map with which they are confronted.

Both moments merge separate sceneries into one paradoxical landscape. The effect destabilizes both history and geography, and it suggests the construction of a heterogeneous filmic environment, made up of distinct spatial and temporal layers and of the articulation of disparate elements. One may rightly take this diverse and multilayered space as a description of the complex territory our dossier aims to chart: Portuguese cinema as it is seen today.

From the beginning, our chief aim in bringing together this special dossier been to provide, through a combination of different contributions, a response to the very concept of "Portuguese cinema." With their own varied critical standpoints, the essays brought together here point to a possible cartography of Portuguese film based not on a previous delimitation of the implications of the adjective "Portuguese" in historical, geographical, or even national terms, but instead determined precisely by indeterminacy. The map of Portuguese cinema 
that emerges here does not take for granted any previous definition of the two words in the title but instead invites readers to rethink both evolving concepts.

It comes as no surprise, then, that the set of texts responding to our challenge all share a common interrogative posture, addressing at the same time concepts and theories of cinema and ideas of history, geography, and identity within Portuguese film. We may take, for instance, Tiago Baptista's analysis of the fake documentary in recent Portuguese film, in which the exposure of the materiality and artificiality of the medium through recourse to montage of archival material allies itself with a questioning and an emergence of an "alternative history" (understood broadly) in recent Portuguese and European fiction. Or Maria Irene Aparício's interrogation of the figure of the "portrait" in Manoel de Oliveira as an instance of a physiognomy of cultural memory deeply rooted in the ontology of the medium. These pieces make visible common concerns found throughout this special dossier: Portuguese history, the history of Portuguese cinema, and some maps and figures questioned in a fruitful combination of theoretical, comparative, and analytic gestures fostered by the complexity of the films at stake. A remapping of the heterogeneity of Portuguese cinema is thus conveyed through a rewriting of its own history, as in Carolin O. Ferreira's panoramic proposal of a reconsideration of hope in the history of Portuguese New Cinema, or through a rereading of representations of Portuguese history, as in António Preto's analysis of national myths and identity in Oliveira, Pedro Costa, and Miguel Gomes, and in Sérgio Dias Branco's discussion of national self-representation in Um adeus português. Fernando Arenas's questioning of the kaleidoscopic dimensions of immigration for Portugal, along with contributions by Tiago Baptista and Maria Irene Aparício, further develop this line of inquiry. This heterogeneity also finds expression through Portuguese cinema's cartographic gestures, as in Patrícia Vieira's and Filipa Rosário's examination of landscape in Portuguese cinema, or finally through this cinema's figurative and reflexive stances, as in Estela Vieira's reading of the functions of walls in Costa's cinema and Clara Rowland's analysis of letter-writing in the work of Oliveira.

Combining essays that are panoramic in nature with more specific readings of particular trends, films, or filmmakers, this dossier explores the two-fold interrogation one can sketch from its title: an interrogation of the ways Portuguese cinema reflects both on its relation to a complex historical 
cartography and a reflection on a multifaceted (and changing) medium. In this sense, our proposal may be divided into two main blocks, broadly structured around two different axes, temporal and spatial, however intertwined their questionings are revealed to be.

In the first section, we included a set of articles that seem to share a preoccupation with temporal configurations, both of history or cultural memory, and of film as a medium and its relation to time. Ferreira, providing a panoramic reading of those films considered part of the Portuguese New Cinema, confronts an established view that sees these films as apolitical and fatalistic. She suggests that a closer look at the overlapping of old and new elements and the complex dialogue between sacrifice and future hope (in Bloch's terms) can generate a different understanding of these films, one that is more keenly aware of their political gestures. Preto, through a comparative reading of historical representations in three films (Oliveira's Non, ou a vã glória de mandar, Gomes's Tabu and Costa's Cavalo dinheiro), suggests that a work of memory is at stake, one that allows for a necessary subjectivization of historical representations if Portugal is to construct a self-image adequate to the present. Dias Branco also tackles representations of history through the depiction of the colonial wars and focuses on the interplay of memory and forgetfulness. He argues, through a close reading of Botelho's Um adeus português, that the film is, in essence, a plea for the Portuguese to discuss a repressed past.

Baptista's and Aparício's essays confront the re-reading of history in Portuguese cinema, and the complex temporality of its representations, but they do so through an explicit questioning of the materiality of the medium and of its mechanisms of representation. Baptista's insightful consideration of what critics have called "filmes de apropriação," a concept that follows from Jamie Baron's work on the use of archival images in Portuguese cinema, leads him to a reading of two recent short films, Redemption (Gomes, 2013) and A glória de fazer cinema em Portugal (Manuel Mozos, 2015), that approaches these films as political interventions by calling attention to their potential in revealing the mechanisms of meaning at stake in cinema and historiographic knowledge alike. Aparício's reading of Oliveira's Cristovão Colombo, o enigma brings forth an instigating hypothesis on the "portrait" in Portuguese cinema, as an enigmatic and interrogative form questioning film's relation to historical 
representations and cultural memory, hovering between fact and fiction, and between the doing and undoing of memory. Closing the section, Rowland's reading of the depiction of letters in Oliveira's Amor de perdição suggests the possibility of reworking his ideas on cinema through the tension this film establishes with the temporality of writing.

In the second section, this dossier's mapping of Portuguese cinema confronts the cartographical gestures at stake throughout its history. Readings of the roles and functions of landscape in Portuguese films are put into dialogue with representations of the Portuguese social and economic spacekaleidoscopic and heterogeneous - through a focus on immigration or with specific figural gestures that are grounded on spatial questionings. The section opens with Patrícia Vieira's panoramic reading of the evolving conceptions of landscape at stake in Portuguese cinema, from the country's early productions to a selection of contemporary films. She argues that one can trace in this environmental evolution many of the important socio-economic and political transformations the country undergoes in the twentieth century, up until the emergence of an ecological consciousness in films such as Gomes's Aquele querido mês de agosto. Rosário provides a thorough systematization of the narrative, visual, and symbolic functions of landscape in Portuguese film through different examples from the 1960s to the present. Monteiro's Veredas (1978) and António Reis and Margarida Cordeiro's Trás-os-Montes (1976) seem to offer the most resistance to some of these recurrent patterns, and Rosário discusses them in detail with respect to their disarticulation of geographical space and the overlapping of geography, myth, and memory. Arenas takes the Portuguese social, cultural, and geographical space of the late twentieth century, in its multicultural and kaleidoscopic configuration determined by immigration, as a site for the interrogation of ideas of community and identity through a comparative reading of two recent acclaimed films, Sérgio Tréfaut's Viagem a Portugal (2011) and Walter Salles and Daniela Thomas's Terra estrangeira (1996), as well as in Brazilian author Luiz Ruffato's recent novel, Estive em Lisboa e lembrei de você (2009), which is set in Portugal. Closing our dossier, Estela Vieira's reading of the representation of walls in Costa's $O$ sangue brings together some of the main lines of questioning at stake in this special issue. Costa's cinema employs walls, windows, doors, and gates in complex ways; for example, they can simultaneously separate and 
reconnect disparate elements. This essay suggests that spatial representations in Costa's cinema function both as meta-cinematic gestures and as reflections on the idea of community (or nation) itself.

The scholarly attention paid to Portuguese cinema in recent years is striking. Notable are the diverse volumes focused on novel approaches to Portuguese film history published by Edições 70 . We are very pleased that this special dossier of the Journal of Lusophone Studies brings to a wider audience a resonant collection of essays authored by some of the foremost specialists responsible for revitalizing the field. Patrícia Vieira's Portuguese Film, 19301960: The Staging of the New State Regime is one of the few books in English exclusively devoted to Portuguese cinema. It joins Randal Johnson's 2007 book on Oliveira, a director on whom Preto has published widely in Portuguese. Ferreira has organized and edited numerous collections devoted to the history of Portuguese cinema, including $O$ cinema português através dos seus filmes (2014), and she has also done much to position Portuguese cinema within its wider postcolonial and transnational Lusophone context. Baptista, one of the editors of a vibrant academic journal in Portugal devoted to cinema (Aniki: Portuguese Journal of the Moving Image) and a dedicated theorist of Portuguese film history, is himself the author of A invenção do cinema português (2008). These important publications, and many others, have not only given more visibility to Portuguese cinema but have also developed more refined ways of conceptualizing and confronting its complexities. Similarly, the contributions found in this dossier persistently reveal what is at stake in the political, cultural, and historical idea of Portuguese cinema, while engaging in close readings that draw connections between the ways in which visual form and methodology reflect broader questions on the role of cinema.

\section{Works Cited}

Baptista, Tiago. A invenção do cinema português. Tinta-da-china, 2008.

Ferreira, Carolin O., editor. O cinema português através dos seus filmes. Edições 70, 2014.

Johnson, Randal. Manoel de Oliveira. U of Illinois P, 2007.

Vieira, Patricia. Portuguese Film, 1930-1960: The Staging of the New State

Regime. Translated by Ashley Caja, Bloomsbury, 2013. 